\title{
The Effects of Tandem Stance Therapy on the Risk of Falling in The Elderly
}

\author{
Ni Made Dwi Yunica Astriani ${ }^{1}$, Putu Indah Sintya Dewi ${ }^{2}$ I Made Sundayana ${ }^{3}$, \\ Made Mahaguna Putra ${ }^{* *}$, I Putu Indra Yudiastu ${ }^{5}$ \\ 1,2,3,4,5 Program Studi Ilmu Keperawatan, Sekolah Tinggi Ilmu Kesehatan Buleleng, Bali \\ *Email: md.mahagunaputra@gmail.com
}

\begin{abstract}
Background: Tandem stance therapy is a therapy that is usually given to the elderly who are at risk of falling. The purpose of this study was to analyze the effect of tandem stance therapy on the risk of falling in the elderly in Giri Emas Village, Sawan District, Buleleng Regency. Methods: The research design was pre-experimental with one group pretest post-test design approach with a sample of 64 respondents selected using a simple random sampling technique. Data collection was performed using the Morse Fall Scale (MFS) questionnaire. This study uses the wilcoxon test. Results: The results showed that the pretest means the value was 2.41 and the post-test score was 2.27. Wilcoxon test results obtained pretest and posttest (0.003) < $<(0.05)$. Conclusion: It was concluded that there was an influence of tandem stance therapy on falling risk in the elderly in Giri Emas Village, Sawan District, Buleleng Regency.
\end{abstract}

Keyword: elderly, fall risk, tandem stance therapy

\section{INTRODUCTION}

Old age shows a process of development as a process of aging. Growing old is a natural process that cannot be denied by humans (Kusuma, 2014). The changes that accompany the elderly can be seen in terms of physical, mental, and presence during their environment, with the changes experienced by the elderly causing indirectly the elderly group has become a group that is number two in the social environment and with their status. the new elderly also need changes to adjust themselves. In addition to this, the elderly will also experience changes marked by changes in appearance, biological changes, changes in the five senses, and changes in sexuality (Supriadi, 2015).

The number of elderly people worldwide is estimated at more than 629 million ( 1 in 10 people over 60 years old), and by 2025 the elderly will reach 1.2 billion (Sari \& Susanti, 2017). The Indonesian state is experiencing developments and advances in the health sector which have led to an increase in life expectancy. Thus, the number of elderly residents will increase. Data from the Central Statistics Agency in 2012 showed that the elderly in Indonesia amounted to $7.56 \%$ of the total population of Indonesia and in 2013 the number of elderly people in Indonesia had reached 20.04 million people or around $8.05 \%$ of the total population of Indonesia (Wahyuni Novianti et al., 2018).

Fall is the biggest threat to the health and independence of the elderly over 60 years and is a cause of death among these ages. The incidence of falls is reported to be very high in the elderly over 65 years. $25-38 \%$ of people over the age of 65 have an increased risk of falling around $32-42 \%$ and nearly one-third of the elderly have experienced falls that result in serious injury. About 1 in 3 elderly people experience serious injuries due to falls, such as hip fractures, and head trauma (Siregar, Gultom, \& Sirait, 2020). Falling events can also be minimized by recognizing risk factors for impaired 
balance, these factors consist of age, physical activity, psychological disorders, disorders of certain medications and cardiovascular diseases such as heart disease and orthostatic hypertension. (Syah, Purnawati, \& Sugijanto, 2017).

Based on preliminary studies using secondary data from community health centers conducted by researchers on January 24, 2019, from data in Giri Emas Village, Sawan District, Buleleng Regency and coordination with Sawan I Community Health Center, the number of elderly people at risk of falling 77 people consisting of 31 people with male sex and 46 with female sex from a total of 297 elderly people.

The results found that the elderly who experience impaired balance in the elderly can be corrected through muscle strengthening exercises that are starting to weaken (Sudrajat \& Sutardji, 2015) like tandem walking exercises (Nugraha, Wahyuni, \& Muliarta, 2016; Prasetyo \& Indardi, 2015). For exercise movements, the tandem walking method can increase muscle strength in the quadriceps muscle area, where the quadriceps muscle is a part of the body whose task is to straighten the knee and bend the hip. However, this study did not involve elderly people who experienced progressive diseases such as diabetes mellitus (DM), hypertension, rheumatoid arthritis (RA), and osteoarthritis (OA). While the elderly are very susceptible to degenerative diseases such as RA, OA, $\mathrm{DM}$, and hypertension. Tandem road is a test and also an exercise that is done by walking in a straight line in the position of the heel of the foot touching the other toe as far as 5-6 meters, this exercise can improve the lateral postural balance, which plays a role in reducing the risk of falling in the elderly. It is one of the types of balance exercises that involve proprioceptive to body stability (Siregar et al., 2020).

Tandem walking exercise is one of the exercises aimed at training posture or body position, controlling balance, muscle coordination, and body movements. Tandem walking exercises are also used to train parameters related to mobility balance (Munawwarah \& Nindya, 2015). But there are still few studies on the effects of tandem paths on the balance of the body of the elderly. Based on the description above, there are still many elderly people who experience the risk of falling, therefore researchers are interested in researching the effect of tandem stance therapy on the risk of falls in the elderly in Giri Emas Village, Sawan District, Buleleng Regency.

\section{METHODS}

One Pretest Posttest study in which this design did not use a comparison group (control), which at least could be done in the first study (pretest) in question, changes that occur after the trial (program) (Notoatmodjo, 2010). The study was conducted from May 10 to June 6, 2019, in Giri Emas Village, Sawan District, Buleleng Regency. The sample in this study was chosen randomly for 64 elderly people aged 60-80 years. Data collection using the Morse Fall Scale (MFS) questionnaire. The results of the validity test of the Morse Fall Scale (MFS) instrument with 30 respondents with validity results of $0.0554-0.4999$, the reliability results of 0.4022 conducted by (Ediawati, 2012). This study uses the wilcoxon statistical test. This research was received by the Health Research Ethics 
Commission of STIKES No. Buleleng. 041 / EC-KEPK-SB / V / 2019.

\section{RESULTS}

Table 1 found that most respondents were in the age range of 6070 years. Respondents were mostly female and a minority were male. All respondents have elementary education level. Before being given tandem stance therapy, the highest risk of falling is the highest risk and the lowest risk of falling is a mild risk. After being given tandem stance therapy, the highest risk of falling is the moderate risk and the lowest risk is the mild risk.

Table 2 shows that $\mathrm{p}=0.001(\alpha=$ $0.05)$. This it can be concluded that there is an effect of providing tandem stance therapy to the risk of falling in the elderly in Giri Emas Village, Sawan District, Buleleng Regency.

Table 1. Characteristics of Respondents

\begin{tabular}{lcc}
\hline \multicolumn{1}{c}{ Characteristics } & $\mathbf{N}=\mathbf{6 4}$ & $\mathbf{\%}$ \\
\hline Age & & \\
$\quad$ 60-70 year & 46 & 71.9 \\
$\quad$ 71-80 year & 18 & 28.3 \\
Gender & 36 & 56.2 \\
$\quad$ Female & 28 & 43.8 \\
$\quad$ Male & & \\
Education level & 64 & 100.0 \\
$\quad$ Elementary school & & \\
Risk of Falling Before Tandem Stance Therapy is Given & 6 & 9.4 \\
$\quad$ 0-24 = Mild Risk & 26 & 40.6 \\
25-44 = Medium Risk & 32 & 50.0 \\
$\quad$ >45 = High risk & & \\
Risk of Fall After Tandem Stance Therapy & 8 & 12.5 \\
$\quad$ 0-24 = Mild Risk & 31 & 48.4 \\
25-44 = Medium Risk & 25 & 39.1 \\
$\quad>45=$ High risk
\end{tabular}

Table 2. Effects of Tandem Stance Therapy On Falling Risk

\begin{tabular}{llcccc}
\hline & & N=64 & Mean Rank & Sum of Ranks & P \\
\hline Pre-Test & Negative Ranks & 9 & \multirow{2}{*}{5,00} & 45,00 & 0,003 \\
Post-Test & Positive Ranks & 0 & & & \\
\hline
\end{tabular}

\section{DISCUSSION}

The risk of falls that occur in the elderly in Giri Emas Village, Sawan District, Buleleng Regency during the interview, most of the elderly complained of experiencing weakness and decreased physical strength and muscle tightness in the legs when starting to walk or when walking, so often disrupting balance when walking and not infrequently there are elderly who experience falls due to loss of balance. The result of the mean risk of falling before being given a tandem stance exercise is 2,41 and after being given an 
intervention the average risk of falling is 2.27. This study proves the influence of tandem stance therapy on the risk of falling in the elderly in Giri Emas Village, Sawan District, Buleleng Regency. Research by Nugrahani (2014) the results of the study showed that of the 28 respondents selected based on a simple random sampling technique and then divided into 2 groups that received tandem walking exercises they received $p=0,000$ $(\mathrm{p}<\alpha)$. Other research results by (Vereeck, Wuyts, \& Truijen, 2008) states there is a change in the mean value before and after the treatment is given from 20.0 to 14.1. The results of other studies are supportive Amick, Chaparro, Patterson, \& Jorgensen, (2015) an increase in balance to reduce the risk of falling by a value of $86.90( \pm 914.37)$ to $89.90( \pm 911.19)$. So there is the effect of tandem walking exercises to improve balance to reduce falls in the elderly.

This shows that there are significant differences in the average value of dynamic balance before and after the tandem road training is given. Indicates a valid decline in the Morse Fall Scale (MFS) scores. Elderly who have decreased risk of falling due to elderly who are cooperative, passionate and serious in doing tandem stance therapy, while some elderly people still have the same falling risk score after doing tandem stance therapy due to the inability of the elderly to follow or make perfect movements so the expected effect is not achieved to the maximum.

\section{CONCLUSION}

Most respondents were female, the highest age was 80 years old, the highest risk of falling was high risk, with the overall education of the respondents being an elementary school. The influence of tandem stance therapy on the risk of falling in the elderly in Giri Emas Village, Sawan District, Buleleng Regency. The procedure of implementing tandem stance therapy can be used by nurses and other health professionals in dealing with the risk of falling in the elderly and can be used as a reference in improving the skills of nurses and other medical personnel in providing care to the elderly who are at risk of falling.

\section{REFERENCES}

Amick, R. Z., Chaparro, A., Patterson, J. A., \& Jorgensen, M. J. (2015). Original Article Test-Retest Reliability of The Sway Balance Mobile Application. Journal Of Mobile Technology In Medicine, 4(2).https://Doi.Org/10.7309/Jmtm. 4.2 .6

Ediawati, E. (2012). Skripsi Gambaran Tingkat Kemandirian dalam Activity of Daily Living (Adl) dan Risiko Jatuh pada Lansia. Skripsi Universitas Indonesia. Depok.

Kusuma, A. K. H. (2014). Pengaruh Terapi Benson. Skripsi Universitas Muhammadiyah.

Munawwarah, M., \& Nindya, P. (2015). Pemberian Latihan pada Lansia dapat Meningkatkan Keseimbangan dan Mengurangi Resiko Jatuh Lansia. Jurnal Fisioterapi, 15, 3844.

Notoatmodjo, S. (2010). Metodologi Penelitian Kesehatan. Jakarta. 
Nugraha, M. H. S., Wahyuni, N., \& Muliarta, I. M. (2016). Pelatihan 12 Balance Exercise Lebih Meningkatkan Keseimbangan Dinamis daripada Balance Strategy Exercise pada Lansia Di Banjar Bumi Shanti, Desa Dauh Puri Kelod, Kecamatan Denpasar Barat. Majalah Ilmiah Fisioterapi Indonesia, 4(1).

Nugrahani. (2014). Latihan Jalan Tandem Lebih Baik daripada Latihan dengan Menggunakan Swiss Ball Terhadap Peningkatan Keseimbangan Untuk Mengurangi Resiko Jatuh pada Lanjut Usia (Lansia). Jurnal Fisioterapi, 14, 87-96.

Prasetyo, A., \& Indardi, N. (2015). Peningkatan Keseimbangan Postural Menggunakan Pengukuran Berg Balance Scale (Bbs) Pada Lansia Di Sasana Panti Mulyo Sragen. Jssf (Journal Of Sport Science And Fitness), 3(4).

Sari, M. T., \& Susanti. (2017). Gambaran Kualitas Hidup Lansia di Panti Sosial Tresna Werdha Budi Luhur dan Lansia di Kelurahan Paal V Kota Jambi. Jurnal Ilmiah Universitas Batanghari, 17(2), 178183.

Siregar, R., Gultom, R., \& Sirait, I. I. (2020). Pengaruh Latihan Jalan Tandem Terhadap Keseimbangan Tubuh Lansia untuk Mengurangi Resiko Jatuh di Upt Pelayanan Sosial Lanjut Usia Binjai Sumatera Utara. Journal of Healthcare Technology And Medicine, 6(1).
Sudrajat, W. A., \& Sutardji. (2015). Efek Pemberian Latihan Keseimbangan dalam Mempertahankan Kemampuan Keseimbangan Manula Panti Wredha Rindang Asih 1 Ungaran. Journal Of Sport Science And Fitness, 3(1).

Supriadi. (2015). Lanjut Usia dan Permasalahanya. Jurnal Ppkn \& Hukum, 10, 84-94.

Syah, I., Purnawati, S., \& Sugijanto. (2017). Efek Pelatihan Senam Lansia dan Latihan Jalan Tandem Sosial Tresna Kasih Sayang Ibu Batusangkar Sumatra. Sport And Fitness Journal, 5(1), 8-16. Https://Doi.Org/10.1080/036053009 03419791

Vereeck, L., Wuyts, F. L., \& Truijen, S. (2008). Clinical Assessment Of Balance: Normative Data, And Gender And Age Effects. International Journal Of Audiology, (February 2017). Https://Doi.Org/10.1080/149920207 01689688

Wahyuni Novianti, I. G. A. S., Jawi, I. M., Munawaroh, M., Griadhi, I. P. A., Muliarta, M., \& Irfan, M. (2018). Latihan Jalan Tandem Lebih Meningkatkan Keseimbangan Lansia daripada Latihan Balance Strategy. Sport And Fitness Journal. Https://Doi.Org/10.24843/Spj.2018. V06.I01.P15 